\title{
Role of serotiny on Pinus pinaster Aiton germination and its relation to mother plant age and fire severity
}

\author{
Oscar Cruz, \\ Juan García-Duro, \\ Mercedes Casal, \\ Otilia Reyes
}

\begin{abstract}
Serotiny degree may hypothetically depend on mother plant age and fire severity, and fire severity can strongly affect the regeneration of Pinus pinaster Aiton, which is an obligate seeder species with aerial seed banks stocked in cones showing a certain degree of serotiny. The main objective of this study was to evaluate the effect of serotiny and mother plant age on seed germination of $P$. pinaster in relation to fire severity. For this purpose, cones were collected in two stands from mother trees of different ages. Serotinous cones were opened in oven at increasing temperatures to determine the number of seeds released. The length of cones and the number and weight of seeds were measured. Seeds from both classes of mother plant age were subjected to 34 different treatments simulating different fire severity levels, and their germination was recorded. The results showed that serotiny was significantly higher in cones from young mother trees. Seed germination in the control groups from serotinous cones was always higher than that from non-serotinous cones without thermal shock. Fire severity decreased seed germination as fire severity increases in both mother age classes. Mother plant age was related to the serotiny level, which was higher in young than in old trees, suggesting a strong selection in the population due to a recent fire.
\end{abstract}

Keywords: Fire Severity, Germination, Mother Plant Age, Pinus pinaster, Plantation Management, Serotiny

\section{Introduction}

Fire is probably the main disturbance affecting natural or semi-natural plant communities, and it is especially relevant in Mediterranean areas because of the high temperatures and summer droughts (Moreira et al. 2012). Forest fires threaten local biodiversity and are an important source of carbon emissions (Davies \& Unam 1999). It is forecast that fire frequency and severity will increase in Europe due to land use and climate change, causing large-scale deforestation and soil erosion (Lloret 2004). Fire severity refers to the loss or decomposition of organic matter aboveground and belowground (Keeley 2009).

Pine forest is one of the Mediterranean ecosystems most impacted by fire (González De Vega et al. 2016). Mediterranean pine species live in fire-prone environments (Trabaud 1995, Hernández-Serrano et al.

2014) and they have developed strategies to survive fires, such as serotiny (Rodrigo et al. 2004, De Las Heras et al. 2012). In serotinous cones, seed release occurs in response to an environmental trigger such as fire, rather than spontaneously at cone maturation. Seeds which are locked in their cones and released after the fire, can germinate immediately when the conditions are favorable, thus restoring the population burned by fire (Vega et al. 2008). Serotiny is a frequent feature in the genus Pinus (Otto et al. 2010, Tapias et al. 2004) and great differences have been found at the interpopulation level in P. pinaster (Tapias et al. 2001, Hernández-Serrano et al. 2013) and even at the individual level within populations (Vega 2000). The increase in fire frequency can alter the resilience of pine trees to fire, so that the shorter the fire time interval, the more the serotinous

$\square$ Área de Ecología, Dpto. de Biología Funcional, Fac. de Biología, Universidad de Santiago de Compostela, Campus Vida, 15782 Santiago de Compostela (Spain)

@ Oscar Cruz (oscar.cruz@usc.es)

Received: Oct 04, 2018 - Accepted: Aug 08, 2019

Citation: Cruz O, García-Duro J, Casal M, Reyes $O$ (2019). Role of serotiny on Pinus pinaster Aiton germination and its relation to mother plant age and fire severity. iForest 12: 491-497. doi: 10.3832/ifor2968-012 [online 2019-11-02]

trees are selected within populations (Hernández-Serrano et al. 2013). If fire frequency exceeds the minimum time for the pines to produce viable seeds, their persistence could be compromised. On the other hand, if the time between two consecutive fires on the same area greatly increases the serotiny could be lost due to maintenance costs (Martín-Sanz et al. 2016), to climatic factors or both (Espelta et al. 2011, MartínSanz et al. 2016).

The mother plant age could be related to the frequency of fires, as mother plants in fire-prone environments are usually young, while in environments with sporadic fires mother plants may live longer and become old (Hernández-Serrano et al. 2013). Moreover, mother plants determine the size and protection of propagules and where, when and how propagules are dispersed (Mousseau \& Fox 1998). Mother plant age affects seed germination and size of seeds and seedlings in some perennials plants (Lembicz et al. 2011). However, there is a very little research on the effects of mother plant age on germination in relation to fire (Cruz et al. 2017). The severity, frequency and extent of fires are key factors in determining the degree of serotiny of populations (Gauthier et al. 1996, Vega et al. 2008, Vincenzi \& Piotti 2014). Furthermore, fire severity has important effects on natural regeneration of tree species like $P$. pinaster (Niccoli et al. 2019). Different studies investigated the effect of factors associated with the severity of fire, such as ash, thermal shocks 
or smoke, on the germination of $P$. pinaster (Escudero et al. 1999, Alvarez et al. 2007), but little has been studied on the combination of both fire severity and mother tree age (Cruz et al. 2017).

To assess the effects of mother plant age and fire severity on cone serotiny and seed germination of $P$. pinaster we hypothesised that: (1) serotiny is affected by mother plant age within the same population; (2) the germination of $P$. pinaster seeds is independent of the level of serotiny, but not of the age of mother trees; (3) fire severity reduces the germination rate of $P$. pinaster seeds independently of the age of mother trees.

\section{Materials and methods}

Cones and seeds were randomly collected in two stands in a P. pinaster Atlantic population in Baio, NW Spain (43 $03^{\prime}$ 14.42" N, $08^{\circ} 57^{\prime} 22.46^{\prime \prime} \mathrm{W} ; 43^{\circ} 09^{\prime} 14.06^{\prime \prime} \mathrm{N}$, $08^{\circ} 57^{\prime} 22.46^{\prime \prime} \mathrm{W}$ ), from May to July 2015 (Fig. 1). The study area consists of small elevated areas with gentle slopes at an altitude of $200 \mathrm{~m}$ a.s.l. The parent rock is mostly gneiss, although there is also granite and schists and the soil is acidic $(\mathrm{pH}=$ 4.72 - PSG 2018). Average annual rainfall and temperature were $1470 \mathrm{~mm}$ and 12.5 ${ }^{\circ} \mathrm{C}$, respectively (Meteogalicia 2019). The area is mostly covered by conifer plantations.

Following Willian (1985) and ENSCONET (2017), cones were directly collected from mother trees in stands with different tree ages: the first group of cones were sampled from 15 trees older than 70 years (approximately 10 cones per tree) recruited after felling, while the other group from 11 young trees ( 9 years or less, approximately 5 cones per tree) recruited after a stand-replacing wildfire in 2006 that partially affected the old population. The age of trees was communicated by the owners of both stands. Overall, 133 cones were collected in the old trees stand ( $O$ trees) and 52 cones in the young trees stand ( $\mathrm{Y}$ trees). In both stands, two groups of cones, serotinous and non-serotinous cones ( $\mathrm{S}$ and NS cones, respectively) were established according to the criteria described by Tapias et al. (2001). The colour of the serotinous cones was bright brown in trees with contrasted ages, so it was assumed that the age of cones in the canopy was similar. All the cones in the $Y$ trees stand were $S$ cones.

The length of cones and the number and weight of seeds in every cone were measured. In NS cones the seeds were freely released after exposure to ambient temperature, while seeds from $\mathrm{S}$ cones were exposed to thermal shocks of 45, 50, 55, $60,65,70$ and $75^{\circ} \mathrm{C}$ using a forced air oven. Exposure time at thermal shocks was determined by the end of cone opening. Each thermal shock made to the $\mathrm{S}$ seeds of both ages has their respective control.

A tetrazolium test and a germination test were carried out to assess seed viability and the germinative response of seeds from young and old mother plants ( $\mathrm{Y}$ trees and $\mathrm{O}$ trees, respectively), from $\mathrm{S}$ and NS cones under control conditions. Control 1 consisted of seeds from NS cones from $\mathrm{O}$ trees not subjected to heating, control 2 were seeds from NS cones heated at $45^{\circ} \mathrm{C}$ for $18 \mathrm{~h}$, control 3 was obtained with seeds from $\mathrm{S}$ cones of $\mathrm{O}$ trees after exposure at $45^{\circ} \mathrm{C}$ for $18 \mathrm{~h}$ and control 4 consisted of seed from $\mathrm{S}$ cones of $\mathrm{Y}$ trees released after $18 \mathrm{~h}$ of exposure at $45^{\circ} \mathrm{C}$.

To investigate the role of factors related to fire severity on germination, different levels of smoke, charcoal, ash and heat were applied to the seeds (see Tab. S1 in Supplementary Material). Seeds in smoke treatments were settled in a smoke-satu-

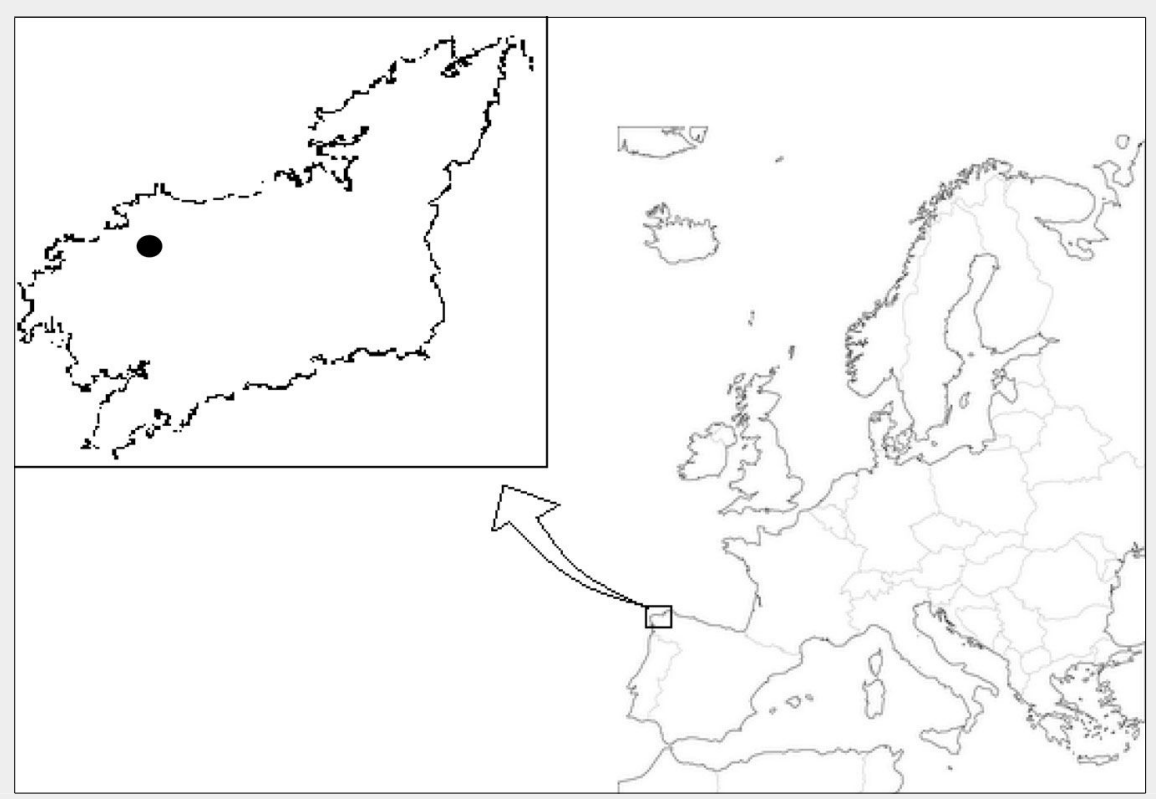

Fig. 1 - Location of the two P. pinaster stands where cones and seeds were collected, in Baio (province of A Coruña), NW Spain. rated chamber for 5, 10 and 15 min resulting in 3 levels of smoke exposure, following the procedure of Reyes et al. (2015a). Two charcoal treatments were applied, one with $P$. pinaster charcoal and the other with Ulex europaeus L. charcoal, as the latter species usually shows a higher biomass share in the understory of pine stands (Reyes et al. 2015a). The seeds were incubated in Petri dish with $0.26 \mathrm{~g}$ of charcoal $\left(411 \mathrm{~kg} \mathrm{ha}^{-1}\right)$ per replicate of the corresponding species. Such amount of charcoal is the same as that measured by Ohlson \& Tryterud (2000) in boreal forest fires of Scandinavia and in other studies in Spain (Reyes et al. 2015b). Ash treatments were ash1 (0.027 g/replicate, $\left.43.5 \mathrm{~kg} \mathrm{ha}^{-1}\right)$, ash2 (0.055 g/replicate, $87 \mathrm{~kg} \mathrm{ha}^{-1}$ ), ash3 (0.11 g/replicate, $174 \mathrm{~kg} \mathrm{ha}^{-1}$ ), ash4 (0.275 g/replicate, $435 \mathrm{~kg} \mathrm{ha}^{-1}$ ) and ash5 ( $0.55 \mathrm{~g} /$ replicate, $870 \mathrm{~kg} \mathrm{ha-1}$ ). These quantities of ash correspond to multiples of data recorded by Soto et al. (1997) after experimental burns on an Atlantic shrubland in SW Europe. The seeds were sown in Petri dishes in the presence of the corresponding quantity of ash from $P$. pinaster. The ash was obtained through total combustion and charcoal from the partial combustion of dry material (mainly branches and leaves) of the selected species. The ash was separated from the charcoal with a $0.4 \mathrm{~mm}$ sieve and the charcoal was separated from the other material with a $2.1 \mathrm{~mm}$ sieve. Afterwards, both the weighted ash and the charcoal were put into Petri dishes. Seeds in thermal treatments were placed within a forced air oven at $80,110,150$ and $200{ }^{\circ} \mathrm{C}$ for 5 and 10 minutes. These temperatures and exposure times correspond to those measured at different soil depths during forest fires and experimental burns by DeBano et al. (1977) in California chaparral, Trabaud (1979) in French garrigues and Bradstock \& Auld (1995) in Mediterranean ecosystems of SE Australia. A full factorial design involving factors fire severity and mother plant age was carried out.

In each treatment 5 replicates of 25 seeds each were put within $9 \mathrm{~cm}$ Petri dishes over cellulose filter paper. Seeds were kept at $24{ }^{\circ} \mathrm{C}$ in light conditions for $16 \mathrm{~h}$ and $8 \mathrm{~h}$ in darkness at $16{ }^{\circ} \mathrm{C}$, to simulate the thermophotoperiod registered in the northwest of the Iberian Peninsula during summer, i.e., the period when more fires occurs (Reyes et al. 2015a). Germination was monitored three times per week until the end of germination test (several days without new germinated seeds in both treatments).

\section{Statistical analysis}

Differences in the proportion of $\mathrm{S}$ cones and NS cones between mother plant ages were analysed using the $\chi^{2}$ test. Differences in cone length and seed weight between (i) $S$ cones and NS cones and (ii) $Y$ trees and $O$ trees were tested using one-way ANOVAs. However, due to the unbalanced factorial design, differences in serotiny were tested 
Fig. 2 - Biometric measures of cones and seeds from young and old plants. (a) Proportion of serotinous and non-serotinous cones;

(b) mean number of spontaneously released seeds from non-serotinous cones and mean number of seeds released from serotinous cones with increasing temperatures; (c) length of serotinous cones; (d) mean weight of seeds from serotinous and non-serotinous cones. Different letters indicate significant differences between mean values $(P<0.05)$. a

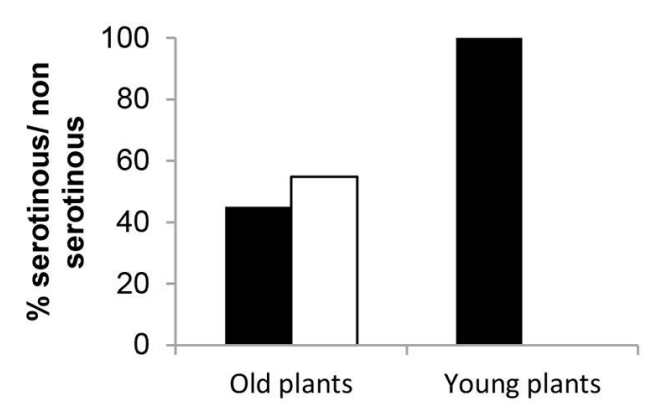

C

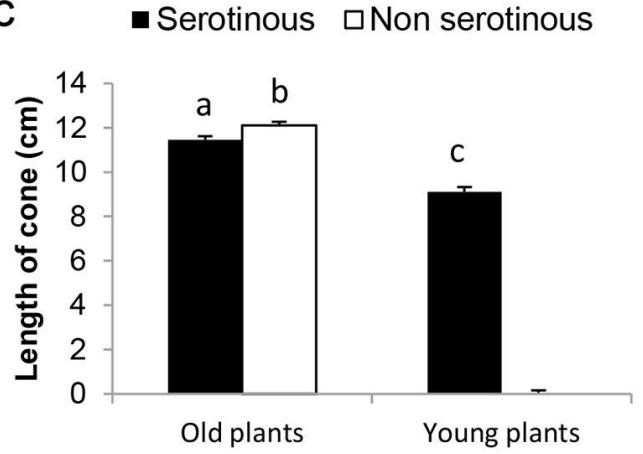

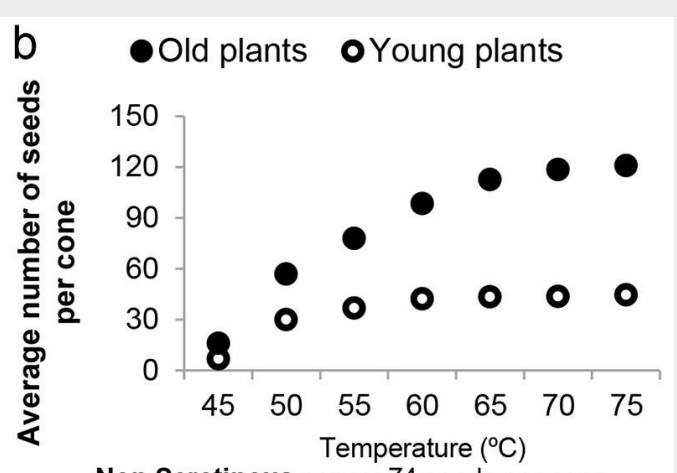

Non Serotinous cones: 74 seeds per cone

d

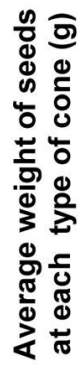

- Serotinous $\square$ Non Serotinous

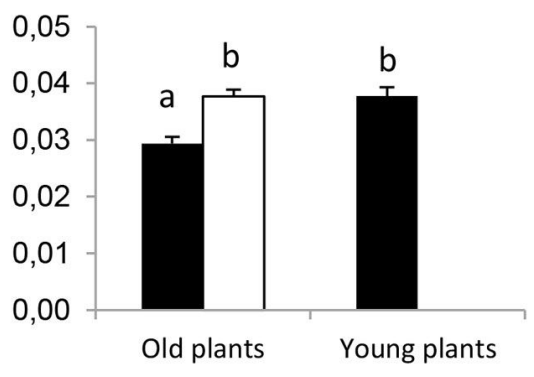

for each level of age, and conversely. Furthermore, a stepwise-regression model based on both backward and forward selection of variables was applied to estimate the seed release from $\mathrm{S}$ cones of $\mathrm{Y}$ and $\mathrm{O}$ trees at increasing temperatures. The significance of every coefficient in the model was further tested by ANOVA procedures. The Akaike information criterion (AIC Akaike 1974) was used to evaluate the model accuracy in predicting seed release values. Let $k$ be the number of parameters in the model and $\hat{L}$ the maximum value of the likelihood function for the model. Then the AIC value of the model is the following (Akaike 1974 - eqn. 1):

$$
A I C=2 k-2 \ln (\hat{L})
$$

Differences in germination among the four controls were tested by one-way ANOVA. Two-way ANOVA tests were conducted to detect significant differences in the percentage of germination between both fire severity treatments and mother plant age. Duncan's multiple range test was used to test for significant differences among treatments. To meet the assumptions underlying the analysis of variance, percentage of germination data was transformed as $x^{2 / 3}$, when necessary. The software used for the above analyses were $R$ ver. 3.2.1 (R Core Team 2015) and SPSS ${ }^{\oplus}$ statistics ver. 20.0 (IBM, Armonk, NY, USA).

\section{Results}

\section{Serotiny}

The mother plant age affects cone serotiny level within the same population of $P$. pinaster. All 52 cones in the $Y$ trees stand were classified as S cones, while NS cones were more numerous than $\mathrm{S}$ cones (73 vs. 60 ) in the $O$ trees stand (Fig. 2a). The $\chi^{2}$ test revealed highly significant $(p<0.001)$ differences between mother plant ages.

Large differences were found in the number of seeds released from $\mathrm{S}$ cones of the $\mathrm{O}$ trees compared with the $\mathrm{Y}$ trees (Fig. $2 b$ ). Seed releasing from $S$ cones increased with rising temperatures. Cone scales of $S$ from both ages began to open releasing seeds at $45{ }^{\circ} \mathrm{C}$, while a small number of seeds were released at temperatures over $60{ }^{\circ} \mathrm{C}$. A total number of 45 seeds per cone was obtained in $\mathrm{S}$ cones of $\mathrm{Y}$ trees. The number of released seeds from $S$ cones of $O$ trees progressively increased as temperature rose up to $70^{\circ} \mathrm{C}$, reaching an asymptotic mean value of 121 seeds per cone. An intermediate number of seeds (74 seeds per cone) were spontaneously released from NS cones of O trees.

The cubic model for seed release (RS) from $S$ cones with increasing temperatures (eqn. 2) fitted well to data (adj- $R^{2}=0.997$ ), revealing highly significant differences between $\mathrm{Y}$ trees and $\mathrm{O}$ trees. All terms in the model were highly significant $(P<0.001)$ regardless of the significant effect of coefficient $c(P<0.01$ - eqn. 2$)$ :

$$
R S=a T+b T^{2}+c T^{3}+d R+e R T^{2}+f T^{3}
$$

where $T$ is the temperature in degrees Celsius, $R$ is the age level, and $a, \ldots, f$ are the coefficients in the cubic model.

Cones of $\mathrm{O}$ trees showed a higher mean length than cones from $\mathrm{Y}$ trees (12.11 vs. $9.11 \mathrm{~cm}-$ Fig. 2C). Highly significant differences $(P<0.001)$ in cone length were detected between $Y$ and $O$ trees, as well as between NS and $\mathrm{S}$ cones from $\mathrm{O}$ trees $(\mathrm{P}<$ 0.007 ).

Seeds from NS cones of $O$ trees and those from $S$ cones of $Y$ trees had the same weight ( $0.038 \mathrm{~g}, \mathrm{P}>0.05)$, whereas the seeds from $S$ cones of $O$ trees were lighter $(0.026 \mathrm{~g})$ than both previous groups (Fig. 2d). Highly significant differences in seed weight from $S$ cones were detected by ANOVA, depending on mother plant age ( $P$ $<$ 0.001). Significant differences in seed weight were also found between $S$ cones and NS cones of $O$ trees $(P<0.001)$.

\section{Germination percentage}

The viability of seeds from $S$ cones (SS) was $89.9 \pm 7.7 \%$ and that of seeds from non serotinous cones (SNS) was $38.4 \pm 6.1 \%$. Seed germination in control conditions was affected by cone serotiny, being higher in $\mathrm{S}$ than in NS cones. The germination of seeds from NS cones from O trees (control 1) was $13.6 \%$. When these seeds were heated at 45 ${ }^{\circ} \mathrm{C}$ for $18 \mathrm{~h}$ (control 2) the germination was $20.8 \%$, with no significant differences between treatments $(P=0.161-$ Fig. 3$)$. The germination of seeds from $\mathrm{S}$ cones of $\mathrm{O}$ trees (control 3) and that of seeds from $\mathrm{S}$ cones of $Y$ trees (control 4) had comparable values (27.2\% and $25.6 \%, P>0.05)$.

Significant differences were found between control 1 and control 3 , and between control 1 and control $4(P<0.05)$. Contrary to expectations, we found that mother plant age and cone serotiny do not, by themselves, affect $P$. pinaster seed germination.

The germination percentage of seeds from $Y$ trees was always higher than that of seeds from $O$ trees (Fig. 4). Highly significant differences in seed germination were 


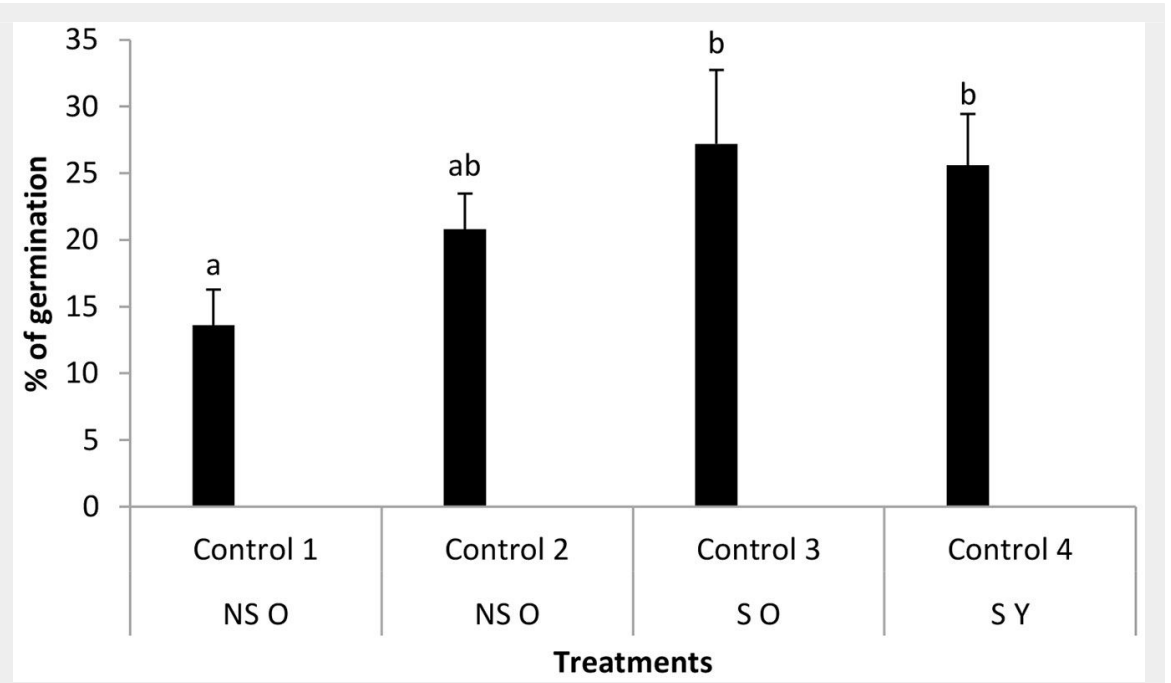

Fig. 3 - Percentage of germination (mean \pm standard deviation) in control conditions depending on mother tree age and cone serotiny. (NS): non serotinous cones; (S): serotinous cones; $(\mathrm{O})$ : old mother trees; $(\mathrm{Y})$ : young mother trees; (Control 1): seeds from NS cones of $\mathrm{O}$ trees without heating; (Control 2): seeds from NS cones of $\mathrm{O}$ trees heated at $45^{\circ} \mathrm{C}$ for $18 \mathrm{~h}$; (Control 3): seeds from $\mathrm{S}$ cones of $\mathrm{O}$ trees released from the cones after exposure at $45^{\circ} \mathrm{C}$ for $18 \mathrm{~h}$; (Control 4): seeds from $\mathrm{S}$ cones of $\mathrm{Y}$ trees released after $18 \mathrm{~h}$ of exposure at $45^{\circ} \mathrm{C}$. Different letters indicate significant differences $(P<0.05)$ between each treatment and the corresponding control of the same mother plant age.

found between age levels and even among fire treatments, though a non-significant interaction between them was detected $(P$ $=0.533$ ).

Fire treatments had similar effect on seeds from both mother plant ages. Smoke treatments (5, 10 and $15 \mathrm{~min}$ ) increased the germination up to $30 \%$ or even more in $\mathrm{Y}$ trees and approximately $20 \%$ in $\mathrm{O}$ trees, though such increase was not statistically significant. P. pinaster charcoal did not alter

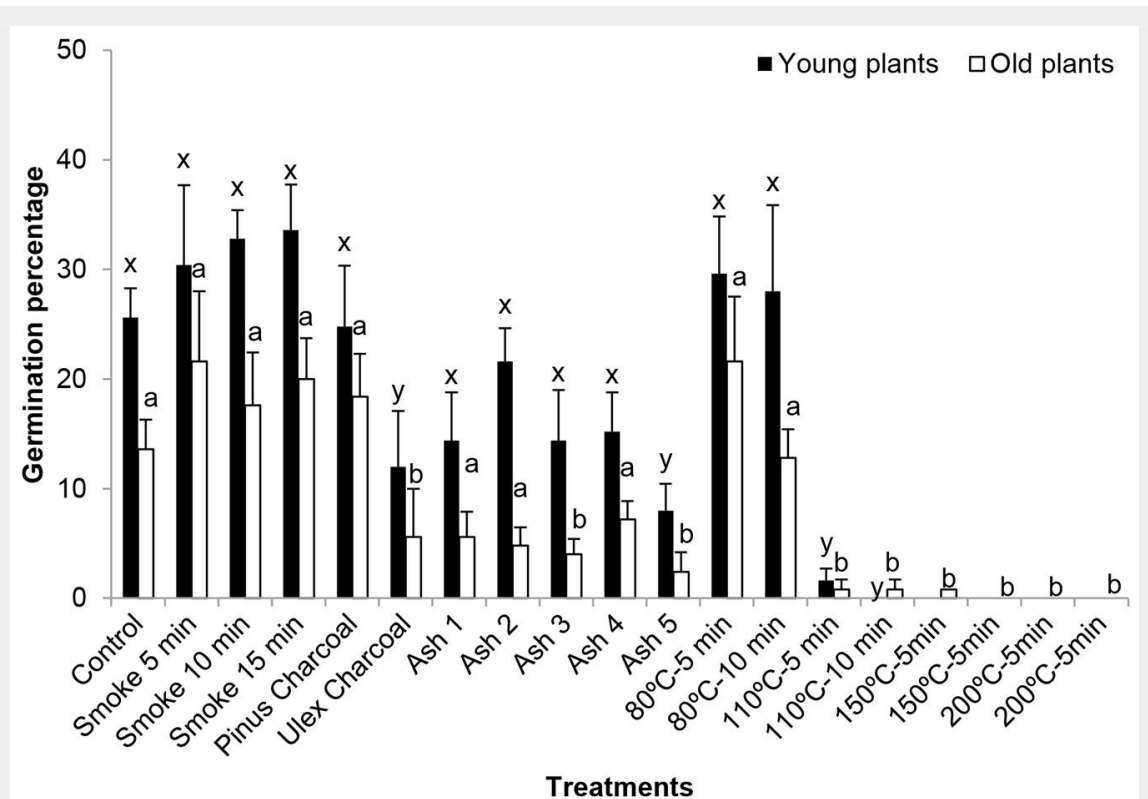

Fig. 4 - Germination percentages (mean \pm standard deviation) of $P$. pinaster seeds from young $(\mathrm{Y})$ and old $(\mathrm{O})$ plants after fire treatments. Different letters indicate significant differences between each treatment and the corresponding control of the same mother plant age. min did not affect germination as compared with the corresponding control values for each age. Nonetheless, the treatment $110^{\circ} \mathrm{C}$ for 5 min strongly reduced germination up to $1 \%$ at both mother plant ages and higher thermal treatments had germination values below $1 \%$, being totally inhibited in many cases. Duncan tests remarked differences between control treatments and $110{ }^{\circ} \mathrm{C}$ for $10 \mathrm{~min}$ at both ages and between control treatment and both $150{ }^{\circ} \mathrm{C}$ for $5 \mathrm{~min}$ and $150^{\circ} \mathrm{C}$ for $10 \mathrm{~min}$ of $\mathrm{Y}$ trees.

\section{Germination timing}

Overall, $P$. pinaster germination over all treatments has spanned 45 days or less. In general, germination rate was higher in the first two or three weeks for treatments showing higher germination (Fig. S1 in Supplementary material). Germination timing of control seeds from $\mathrm{Y}$ and $\mathrm{O}$ trees was clearly different, as most of the latter seeds germinated between days 12 and 17, whereas most control seeds from $Y$ trees did germinate between days 12 and 28 . The smoke treatments slightly delayed the beginning of seed germination, showing higher peaks later compared with controls. Only smoke 5 min treatment on seeds of $O$ trees did not match this pattern, being close to their corresponding control. Germination in charcoal treatments had different temporal distributions according to the charcoal type. Indeed, Pinus charcoal favored more intense peaks of germination on seeds from both $Y$ trees and $O$ trees. Seeds from $O$ trees treated with Ulex charcoal also showed lower levels of germination, though the peaks of germination were concentrated in only two weeks.

Germination of seeds from $O$ trees treated with ash was early ( $<20$ days) but scarce. Seeds from $Y$ trees subjected to Ash 2 treatment showed a high and intense peak of germination during the first 15 days and smaller peaks of germination afterward. Seed germination in the remaining treatments was low but constant, except for Ash 3 and Ash 5, which were 0 at the $33^{\text {rd }}$ and $24^{\text {th }}$ days, respectively.

Finally, the germination events after the thermal shock treatments on seeds from $\mathrm{O}$ trees were disperse over time, producing the maximum germination around day 12 . Peaks of germination of seeds from $Y$ trees were higher and took place at the beginning of the incubation period, between days 7 and 24, being low afterward.

\section{Discussion}

$P$. pinaster is one of the obligate-seeder pine species in the Mediterranean Basin that develops an aerial seed bank through cone serotiny (Tapias et al. 2004). In this study we observed that the degree of serotiny in a $P$. pinaster population was strongly related to the mother tree age. This is in agreement with the results found by Hernández-Serrano et al. (2013) in Mediterranean populations of $P$. pinaster and 
by Martín-Sanz et al. (2016) in P. halepensis. The fact that cones of the young mother plants in this study are all serotinous could be attributed to a strong selection of this hereditary trait induced by fire. Madrigal et al. (2019) also found differences in other fire adaptive traits of Pinus pinea $L$. between study sites, suggesting potential genetic differences induced by wildfires in the past. In our study all cones from the young $(Y)$ trees were serotinous (total serotiny sensu Tapias et al. 2001). Conversely, in old (O) trees only one half of the cones were serotinous $(S)$ and the other half were non serotinous (NS - low serotiny sensu Tapias et al. 2001). It is likely that the vast majority of the seeds dispersed after the 2006 fire were from S cones, while seeds released from NS cones would lie on the forest floor and not survived the fire. Thus, our results are consistent with the hypothesis that a strong selection against non serotinous cones could have taken place in the studied population, leading to the total serotiny observed after the 2006 wildfire in the younger stand. The strategy of establishing an early aerial seed bank minimizes the risk of immaturity (Zedler 1995) and ensures post-fire regeneration. To a lesser extent, the selection for serotiny could also be due to the different development state of the stand. Moreover, Martín-Sanz et al. (2016) found a higher level of serotiny in small trees of $P$. halepensis than in large ones, attributing the lower serotiny to the physical degradation (weathering) of older cones remaining on the crown. Espelta et al. (2011) argue that the maintenance costs of these long-lasting strategy can also be affected by drought.

Mother plant age also plays a remarkable role in determining the temperature at which cones completely opened their scales, but the number of released seeds also depends on cone size and the number of seeds contained. $\mathrm{S}$ cones from $\mathrm{O}$ trees were larger than the $\mathrm{S}$ cones from $\mathrm{Y}$ trees, thereby releasing more seeds. However, other aspects related to cone morphology, cone scale anatomy, water supply, rainfall and temperatures during the cone formation as well as other factors could be involved (Alfaro-Sánchez et al. 2015, MartínSanz et al. 2017).

Cone length is related to the age of mother trees, i.e., cones from $\mathrm{O}$ trees were longer than cones from $\mathrm{Y}$ trees. In the $\mathrm{Y}$ stand trees were very young ( 9 years old) and therefore cone length might still be affected by the maternal effect. The relationship between fertility and mother plant age has been studied to some extent (Tíscar 2002, Ganatsas et al. 2008) and the results have been very diverse, often because age classes of mother plants were very different across studies.

The number and weight of seeds showed an inverse relationship that depends on mother plant age. Indeed, $\mathrm{S}$ cones from $\mathrm{Y}$ trees contained fewer and heavier seeds than $\mathrm{S}$ cones from $\mathrm{O}$ trees. According to Zas \& Sampedro (2015), the number and weight of seeds in $S$ cones could reflect a particular reproductive strategy of mother trees, which consists in producing smaller cones containing fewer and heavier seeds at younger age, and larger cones with more though smaller seeds as mother plants grow older. Furthermore, heavier but fewer seeds were found in NS cones than in $\mathrm{S}$ cones of $\mathrm{O}$ trees. It is very likely that the lesser number of seeds from NS cones is due to summer release before collection (Lanner 1998). Besides, cone-opening begins from apical scales, which contain the smallest seeds in the cone (McGinley et al. 1990), so it is likely that the number and weight of seeds in NS cones before dispersal would have been similar to those in $\mathrm{S}$ cones. At the intrapopulation level, this would lead to an increase in the mean seed weight, together with an increase in the level of serotiny. Thus, the death of old mother trees due to fire could indirectly lead to a greater proportion of heavier seeds at the population level. Accordingly, Calvo et al. (2016) found an inverse relationship between seed weight and the degree of serotiny of three populations of $P$. pinaster. Based on the above considerations, it could be hypothesized that $P$. pinaster has developed strategies to yield high percentages of $\mathrm{S}$ cones with few big seeds to ensure the success of post-fire regeneration in populations subjected to high fire frequency (where all the mother plants were young), probably to face short-term survival under recurrent fire regimes, as found by Alfaro-Sánchez et al. (2015) in Pinus halepensis Mill. in response to recurrent fire regimes or drought episodes. Contrastingly, in low fire frequency habitats (where many mother trees were old) trees bearing low-serotiny cones with a large number of small seeds to be dispersed in years without fires could be favored. More research is needed to look closely at the relation between mother plant age and serotiny.

$P$. pinaster germination in controls was determined by cone serotiny and was related to the heating treatment applied for seed release. Higher germination values were observed for seeds from $\mathrm{S}$ cones (regardless of mother tree age) than for the non-heated seeds from NS cones. This suggests the mother plant age itself did not affect the germination of $P$. pinaster seeds, but it did through its cone serotiny level and the percentages of seed germination from NS and S cones, respectively. Alvarez et al. (2007) also found very high germination values in a $P$. pinaster population with a high degree of serotiny. Germination time under control conditions seems to be negatively related to seed weight, since the only significant difference was found between seeds of $\mathrm{O}$ trees, which were heavier in NS than $\mathrm{S}$ cones. Calvo et al. (2016) also found the same negative relationship between seed weight and germi-

\section{nation time.}

In this study seed exposure to main firerelated factors, such as heat, smoke, ash and charcoal, had different effects on germination percentage in $P$. pinaster, though following a similar pattern at different mother tree ages. Goubitz et al. (2003) did not find differences in seed germination from cones of different age and serotiny in $P$. halepensis. Globally, germination after fire treatments was earlier and slightly increased in seeds from $Y$ trees as compared with $O$ trees. Tessler et al. (2014) found lesser abundance of $P$. halepensis in areas with high fire frequency compared with those subjected to a low fire frequency. This can be due to the fact that in the high fire frequency areas trees are younger and with smaller aerial seed banks, regardless of the higher germination rate of their seeds.

Smoke exposure slightly increased seed germination of both mother plant ages, determining at some doses a significant delay in seed germination, regardless of mother tree ages. Contrasting results are reported in the literature on the effect of smoke in different species, which was stimulating in Mediterranean species (Crosti et al. 2006), and neutral in $P$. pinaster (Reyes \& Casal 2006) and other pine species (Reyes et al. 2015a).

Charcoal treatments had different effects on seeds depending on its type. Pinus charcoal did not affect germination whereas Ulex charcoal strongly reduced seed germination in both mother plant ages. In addition, Ulex charcoal strongly delayed the germination of seeds from $Y$ trees. Other studies revealed negative (Buss \& Mašek 2014), neutral (Reyes \& Casal 2006) or positive effects of charcoal (Reyes et al. 2015b), suggesting that charcoal effect could depend on its nature and on the exposed species.

In this study ash treatments reduced the germination percentage of $P$. pinaster seeds. Ash-treated seeds from $Y$ trees had higher germination values, and their germination timing was more variable than that of seeds from $O$ trees. The inhibition was higher when increasing the ash dose. Reyes \& Casal (2004) also found a significant reduction in $P$. pinaster and other pine species at high ash doses.

Moderate heat treatments of cones for seed release $\left(80{ }^{\circ} \mathrm{C}\right.$ for 5 and 10 minutes) did not affect germination in both mother tree ages, while the remaining treatments strongly reduced or even totally depleted seed germination. In all cases, the germination of seeds from $Y$ trees was greater and less dispersed across time than that of seeds from $O$ trees. When the $110{ }^{\circ} \mathrm{C}$ treatment was applied, germination rate was nearly $1 \%$ and even less for temperatures of $150^{\circ} \mathrm{C}$ or higher. Escudero et al. (1999), Calvo et al. (2013) and Moya et al. (2013) reportes similar results for Pinus germination, with very sharp reductions caused by high fire temperatures. 


\section{Conclusions}

We found that serotiny was higher in $Y$ trees than in $O$ trees in a population of $P$. pinaster. After heating at different temperatures, $\mathrm{S}$ cones released more seeds in $\mathrm{O}$ trees than in $\mathrm{Y}$ trees. Mother plant age did not seem to affect germination either under control conditions or in fire conditions. Treatments with smoke, Pinus charcoal and moderate thermal shocks did not alter seed germination, while Ulex charcoal treatments, high concentrations of ash and thermal shocks at temperatures over $110^{\circ} \mathrm{C}$ for 10 min can strongly reduce germination.

Then, one would expect that the serotiny of a P. pinaster population was linked to mother plant age and indirectly related to fire frequency on the population. The efficiency in the use of resources would lead to pines in high fire frequency areas to produce cones with fewer but bigger seeds that can generate seedlings immediately after fire with higher probability of individual survival. Pines from low fire frequency areas would produce cones with more but smaller seeds intended to germinate in periods between fires. Despite the negative effects of fire on germination, the resulting seedlings could benefit from the lack of competition with other species since the germination of $P$. pinaster is relatively rapid.

For the establishment of $P$. pinaster plantations under the increasing risk of wildfires due to climate change (IPCC 2014), seeds from serotinous cones should be selected to minimize the immaturity risk of $P$. pinaster populations (Zedler 1995), as serotiny allows the maintenance of a large aerial seed bank that is released after fire. Moreover, germination of seeds from serotinous cones is slightly greater and faster than that of seeds from non serotinous cones, ensuring a better and more effective population re-establishment after fire.

\section{Acknowledgements}

The authors are grateful to E. Reyes and E. Ferreira for help with the fieldwork and to J. Casal for fruitful discussions. This work is part of the research projects AGL2013-48189-C2-2-R (Ministerio de Economía y Competividad, Madrid, Spain, and ERDF founding), AGL2017-86075-C2-2-R (Ministerio de Ciencia, Educación y Universidades, Madrid, Spain, and ERDF founding), LE001P17 (Junta de Castilla y León, Valladolid, Spain), ED431C2019/07 and ED431E 2018/og (Xunta de Galicia, Santiago de Compostela, Spain).

\section{References}

Akaike H (1974). A new look at the statistical model identification. Automatic Control 19: 716723. - doi: 10.1109/TAC.1974.1100705

Alfaro-Sánchez R, López-Serrano FR, Rubio E, Sánchez-Salguero R, Moya D, Hernández-Tecles E, De las Heras J (2015). Response of biomass allocation patterns to thinning in Pinus halepensis differs under dry and semiarid Mediter- ranean climates. Annals of Forest Science 72: 595-607. - doi: 10.1007/s13595-015-0480-y

Alvarez R, Valbuena L, Calvo L (2007). Effect of high temperatures on seed germination and seedling survival in three pine species (Pinus pinaster, $P$. sylvestris and $P$. nigra). International Journal of Wildland Fire 16: 63-70. - doi: 10.1071/ WFo6001

Bradstock RA, Auld TD (1995). Soil temperatures during experimental bushfires in relation to fire intensity: consequences for legume germination and fire management in South-Eastern Australia. Journal of Applied Ecology 32: 76-84. doi: $10.2307 / 2404417$

Buss W, Mašek O (2014). Mobile organic compounds in biochar - A potential source of contamination - Phytotoxic effects on cress seed (Lepidium sativum) germination. Journal of Environmental Management 137: 111-119. - doi: 10.1016/j.jenvman.2014.01.045

Calvo L, García-Domínguez C, Naranjo A, Arévalo JR (2013). Effects of light/darkness, thermal shocks and inhibitory components on germination of Pinus canariensis, Pinus halepensis and Pinus pinea. European Journal of Forest Research 132: 909-917. - doi: 10.1007/s10342-0130729-7

Calvo L, Hernández V, Valbuena L, Taboada A (2016). Provenance and seed mass determine seed tolerance to high temperatures associated to forest fires in Pinus pinaster. Annals of Forest Sciences 73: 381-391. - doi: 10.1007/s135 95-015-0527-0

Crosti R, Ladd PG, Dixon KW, Piotto B (2006). Post-fire germination: the effect of smoke on seeds of selected species from the central Mediterranean basin. Forest Ecology and Management 221: 306-312. - doi: 10.1016/j.foreco.2005. 10.005

Cruz O, García-Duro J, Casal M, Reyes O (2017). Can the mother plant age of Acacia melanoxyIon (Leguminosae) modulate the germinative response to fire? Australian Journal of Botany 65: 593-600. - doi: 10.1071/BT17083

Davies SJ, Unam L (1999). Smoke-haze from the 1997 Indonesian forest fires: effects on pollution levels, local climate, atmospheric $\mathrm{CO}_{2}$ concentrations, and tree photosynthesis. Forest Ecology and Management 124: 137-144. - doi: 10.1016/S0378-1127(99)00060-2

DeBano L, Dunn P, Conrad C (1977). Fire's effect on physical and chemical properties of chaparral soils, In: Proceedings of the Symposium "Environmental Consequences of Fire and Fuel Management in Mediterranean Ecosystems" (Mooney HA, Conrad C eds). General Technical Report WO-3, USDA Forest Service, Washington, DC, USA, pp. 65-74.

De Las Heras J, Moya D, Vega JA, Daskalakou E, Vallejo R, Grigoriadis N, Tsitsoni T, Baeza J, Valdecantos A, Fernández C, Espelta J, Fernandes $P$ (2012). Post-fire management of serotinous pine forests. In: "Post-Fire Management and Restoration of Southern European Forests" (Moreira F, Arianoutsou M, Corona P, De las Heras J eds). Managing Forest Ecosystems, vol. 24, Springer, Dordrecht, Netherlands, pp. 121-150. - doi: 10.1007/978-94-007-2208-8_6 ENSCONET (2017). European native seed conservation network. Web site. [online] URL: http:// www.bgci.org/resources/article/0683/
Escudero A, Sanz MV, Pita JM, Pérez-García F (1999). Probability of germination after heat treatment of native Spanish pines. Annals of Forest Sciences 56: 511-520. - doi: 10.1051/for est:19990608

Espelta JM, Arnan X, Rodrigo A (2011). Non-fire induced seed release in a weakly serotinous pine: climatic factors, maintenance costs or both? Oikos 120: 1752-1760. - doi: 10.1111/j.160o0706.2011.19570.x

Ganatsas P, Tsakaldimi M, Thanos C (2008). Seed and cone diversity and seed germination of $\mathrm{Pi}$ nus pinea in Strofylia site of the Natura 2000 Network. Biodiversity and Conservation 17: 2427-2439. - doi: 10.1007/s10531-008-9390-8 Gauthier S, Bergeron Y, Simon JP (1996). Effects of fire regime on the serotiny level of jack pine. Journal of Ecology 84: 539-548. - doi: 10.2307/22 61476

González De Vega S, De Las Heras J, Moya D (2016). Resilience of Mediterranean terrestrial ecosystems and fire severity in semiarid areas: Responses of Aleppo pine forests in the short, mid and long term. Science of the Total Environment 573: 1171-1177. - doi: 10.1016/j.scitotenv. 2016.03.115

Goubitz S, Werger MJA, Neeman G (2003). Germination response to fire-related factors of seeds from non-serotinous and serotinous cones. Plant Ecology 169: 195-204. - doi: 10.1023/ A:1026036332277

Hernández-Serrano A, Verdú M, González-Martínez SC, Pausas JG (2013). Fire structures pine serotiny at different scales. American Journal of Botany 100: 2349-2356. - doi: 10.3732/ajb.1300 182

Hernández-Serrano A, Verdú M, Santos-Del-Blanco L, Climent J, González-Martínez SC, Pausas JG (2014). Heritability and quantitative genetic divergence of serotiny, a fire-persistence plant trait. Annals of Botany 114: 571-577. - doi: 10.109 3/aob/mcu142

IPCC (2014). Climate change 2014: impacts, adaptation and vulnerability. Part A: Global and sectoral aspects. Contribution of Working Group II to the Fifth Assessment Report of the Intergovernmental Panel on Climate Change, Cambridge University Press, Cambridge, UK, pp. 1101-1131.

Keeley JE (2009). Fire intensity, fire severity and burn severity: a brief review and suggested usage. International Journal of Wildland Fire 18: 116-126. - doi: 10.1071/WF07049

Lanner R (1998). Seed dispersal in Pinus. In: "Ecology and Biogeography of Pinus" (Richardson DM, Rundel P eds). Cambridge University Press, Cambridge, UK, pp. 381-395.

Lembicz $M$, Olejniczak $P$, Zukowski $W$, Bogdanowicz AM (2011). Effect of mother plant age on germination and size of seeds and seedlings in the perennial sedge Carex secalina (Cyperaceae). Flora - Morphology, Distribution, Functional Ecology of Plants 206 (2): 158-163. - doi: 10.1016/j.flora.2010.09.006

Lloret F (2004). Régimen de incendios y regeneración [Fire regime and regeneration]. In: “Ecología del Bosque Mediterráneo en un Mundo Cambiante" (Valladares F ed). Ministerio de Medio Ambiente, EGRAFSA, Madrid, Spain, pp. 101-126. [in Spanish]

Madrigal J, Souto-García J, Calama R, Guijarro M, 
Picos J, Hernando C (2019). Resistance of Pinus pinea L. bark to fire. International Journal of Wildland Fire 28: 342-353. - doi: 10.1071/WF18118 Martín-Sanz RC, Santos-Del-Blanco L, Notivol E, Chambel MR, San-Martin R, Climent J (2016). Disentangling plasticity of serotiny, a key adaptive trait in a Mediterranean conifer. American Journal of Botany 103: 1582-1591. - doi: 10.3732/ ajb.1600199

Martín-Sanz RC, Callejas-Díaz M, Tonnabel J, Climent JM (2017). Maintenance costs of serotiny in a variably serotinous pine: the role of water supply. PLoS One 12 (7): e0181648. - doi: 10.137 1/journal.pone. 0181648

MCGinley MA, Smith CC, Elliott PF, Higgins JJ (1990). Morphological constraints on seed mass in Lodgepole pine. Functional Ecology 4: 183-192. - doi: 10.2307/2389337

Meteogalicia (2019). Meteogalicia web site. Conselleria de Medio Ambiente, Territorio e Vivenda, Xunta de Galicia, Spain. [in Spanish] [online] URL: http://www.meteogalicia.gal/web/in dex.action

Moreira $\mathrm{F}$, Arianoutsou $\mathrm{M}$, Corona $\mathrm{P}$, De las Heras J (2012). Post-fire management and restoration of Southern European forests. Springer Science and Business Media, Dordrecht, Netherlands, pp. 330.

Mousseau T, Fox C (1998). The adaptive significance of maternal effects. Trends in Ecology and Evolution 13: 403-407. - doi: 10.1016/So1695347(98)01472-4

Moya D, Heras J, Salvatore R, Valero E, Leone V (2013). Fire intensity and serotiny: response of germination and enzymatic activity in seeds of Pinus halepensis Mill. from southern Italy. Annals of Forest Sciences 70: 49-59. - doi: 10.1007/ s13595-012-0236-x

Niccoli F, Esposito A, Altieri S, Battipaglia G (2019). Fire severity influences ecophysiological responses of Pinus pinaster Ait. Frontiers in Plant Science. 10: 539. - doi: 10.3389/fpls.2019.0 0539

Ohlson M, Tryterud E (2000). Interpretation of the charcoal record in forest soils: forest fires and their production and deposition of macroscopic charcoal. The Holocene 10: 519-525. - doi: 10.1191/095968300667442551

Otto R, García-Del-Rey E, Muñoz PG, FernándezPalacios JM (2010). The effect of fire severity on first-year seedling establishment in a Pinus canariensis forest on Tenerife, Canary Islands. European Journal of Forest Research 129: 499508. - doi: $10.1007 / 510342-009-0347-6$

PSG (2018). Propiedade Solos Galicia, web site. Departemento de Edafologia Y Quimica Agricola, USC, Santiago de Compostela, Spain, web site. [in Spanish] [online] URL: http://rgis.cesga. es/index.html

R Core Team (2015). R: a language and environ- ment for statistical computing. R Foundation for Statistical Computing, Vienna, Austria. [online] URL: https://www.r-project.org/

Reyes O, Casal M (2004). Effects of forest fire ash on germination and early growth of four $\mathrm{Pi}$ nus species. Plant Ecology 175 (1): 81-89. - doi: 10.1023/B:VEGE.0000048089.25497.0c

Reyes O, Casal M (2006). Can smoke affect the germination of Pinus sylvestris, $P$. nigra, $P$. uncinata and $P$. pinaster? Forest Ecology and Management 234 (s15): S184. - doi: 10.1016/j.foreco. 2006.08.303

Reyes O, García-Duro J, Salgado J (2015a). Fire affects soil organic matter and the emergence of Pinus radiata seedlings. Annals of Forest Sciences 72: 267-275. - doi: 10.1007/s13595-0140427-8

Reyes O, Kaal J, Arán D, Gago R, Bernal J, GarcíaDuro J, Basanta M (2015b). The effects of ash and black carbon (biochar) on germination of different tree species. Fire Ecology 11: 119-133. doi: 10.4996/fireecology.1101119

Rodrigo A, Retana J, Picó FX (2004). Direct regeneration is not the only response of Mediterranean forests to large fires. Ecology 85: 716729. - doi: 10.1890/02-0492

Soto B, Basanta R, Diaz-Fierros F (1997). Effects of burning on nutrient balance in an area of gorse (Ulex europaeus L.) scrub. Science of The Total Environment 204: 271-281. - doi: 10.1016/ So048-9697(97)00185-X

Tapias R, Gil L, Fuentes-Utrilla P, Pardos JA (2001). Canopy seed banks in Mediterranean pines of south-eastern Spain: a comparison between Pinus halepensis Mill., P. pinaster Ait., P. nigra Arn. and P. pinea L. Journal of Ecology 89: 629-638. - doi: 10.1046/j.1365-2745.2001.00575.x Tapias R, Climent J, Pardos JA, Gil L (2004). Life histories of Mediterranean pines. Plant Ecology 171: 53-68. - doi: 10.1023/B:VEGE.0000029383.72 609.fo

Tessler N, Wittenberg L, Provizor E, Greenbaum $N$ (2014). The influence of short-interval recurrent forest fires on the abundance of Aleppo pine (Pinus halepensis Mill.) on Mount Carmel, Israel. Forest Ecology and Management 324: 109-116. - doi: 10.1016/j.foreco.2014.02.014

Tíscar P (2002). Capacidad reproductiva de Pinus nigra subsp. salzmannii en relación con la edad de la planta madre [Reproductive capacity of Pinus nigra subsp. salzmannii in relation to the age of the mother plant]. Investigaciones Agrarias: Sistemas y Recursos Forestales 11: 357-372. [in Spanish] [online] URL: http://recyt.fecyt.es/ index.php/IA/article/view/2541

Trabaud L (1979). Etude du comportement du feu dans la Garrigue de Chêne kermès à partir des températures et des vitesses de propagation [Study of fire behavior in the Garrigue de Kermes Oak from temperatures and propaga- tion velocities]. Annals of Forest Sciences 36: 13-38. [in French] - doi: 10.1051/forest/19790102 Trabaud L (1995). Modalités de germination des cistes et des pins méditerranéens et colonisation des sites perturbés [Germination of mediterranean Cistus spp. and Pinus spp. and their reoccupation of disturbed sites]. Revue d'Écologie 1: 3-14. [in French] [online] URL: http://documents.irevues.inist.fr/handle/2042/5 4786

Vega JA (2000). Resistencia vegetativa ante el fuego a través de la historia de los incendios [Vegetative resistance to fire through the history of fires]. In: "La Defensa Contra Incendios Forestales: Fundamentos y Experiencias" (Velez R ed). McGraw-Hill, Madrid, Spain, pp. 6685. [in Spanish]

Vega JA, Fernández C, Pérez-Gorostiaga P, Fonturbel T (2008). The influence of fire severity, serotiny, and post-fire management on Pinus pinaster Ait. recruitment in three burnt areas in Galicia (NW Spain). Forest Ecology and Management 256: 1596-1603. - doi: 10.1016/j.foreco.2 008.07.005

Vincenzi S, Piotti A (2014). Evolution of serotiny in maritime pine (Pinus pinaster) in the light of increasing frequency of fires. Plant Ecology 215: 689-701. - doi: 10.1007/s11258-014-0342-y

Willian RL (1985). A guide to forest seed handling. FAO Forestry Paper 20/2, FAO, Rome, Italy, pp. 379. [online] URL: http://www.fao. org/docrep/006/ad232e/ad232eoo.htm

Zas R, Sampedro L (2015). Heritability of seed weight in Maritime pine, a relevant trait in the transmission of environmental maternal effects. Heredity 114: 116-124. - doi: 10.1038/hdy. 2014.76

Zedler PH (1995). Fire frequency in southern California shrublands: biological effects and management options. In: "Brushfires in California: Ecology and Resource Management" (Keeley JE, Scott T eds). International Association of Wildland Fire, Fairfield, Washington, DC, USA, pp. 101-112.

\section{Supplementary Material}

Fig. S1 - Germination timing in P. pinaster according to the age of mother plants and the tested fire treatments.

Tab. S1 - Germination treatments carried out with seeds from young $(\mathrm{Y})$ and old $(\mathrm{O})$ plants to test the effect of fire severity and mother plant age on the germinative response of $P$. pinaster.

Link: Cruz_2968@supploo1.pdf 